\title{
The unfading power of collegiality? University governance in Poland in a European comparative and quantitative perspective
}

\author{
Marek Kwiek* \\ Center for Public Policy Studies, Director, UNESCO Chair in Institutional Research and Higher Education Policy, Chairholder, University of Poznan Ul. \\ Szamarzewskiego 89, 60-569 Poznan, Poland
}

\section{A R T I C L E I N F O}

\section{Article history:}

Received 18 January 2014

Received in revised form 7 March 2015

Accepted 14 May 2015

\section{Keywords:}

Poland

European universities

University governance

Governance models

Academic collegiality

Collegial bodies

Academic profession

\begin{abstract}
A B S T R A C T
This paper studies the applicability of theoretical models of university governance from the international research literature to the Polish system. In particular, it is to test the applicability of a collegial model in the Polish case. The research question was 'to what extent is a collegial model reflected in actual governance patterns found in the Polish university sector'. This is based on large-scale internationally comparable quantitative material. The empirical evidence for it comes from 3700 returned surveys in Poland (and more than 17,000 in eleven European countries) produced for two international research projects focused on the academic profession (CAP: "Changing Academic Profession" and EUROAC: "The Academic Profession in Europe"). This paper concludes that Polish universities are operating according to the traditional collegial model of the university as a "community of scholars" to an extent that is unparalleled in Western Europe. A detailed study of selected variables and specifically constructed indexes indicates that the defining feature of Polish academia today is the power of academic collegial bodies. The influence of collegial bodies on academic decision-making in Poland is the highest in Europe; and, in contrast, the power of the government and external stakeholders is the lowest. However, academics, sharing the "republic of scholars" institutional vision of the university, and still highly influential in university decision-making, are currently confronted with higher education reforms grounded in an instrumental vision of the university (in which it is a tool for national political agendas). Consequently, powerful value-driven clashes between the academic community and the community of policymakers and reformers are to be expected to intensify. The major theoretical concepts used in this paper come from Johan P. Olsen's, Ian McNay's and Robert Birnbaum's studies of university governance, and its findings are presented from a European comparative and quantitative perspective.
\end{abstract}

(c)2015 Elsevier Ltd. All rights reserved.

\section{Introduction}

Poland is the 5th largest higher education system in the European Union today and subject to powerful reform pressures linked to the processes of Europeanization and globalization. Its university governance and funding modes are radically changing, especially since 2010 when a new wave of governance and funding reforms started (Kwiek, 2014b). But can an emergent (post-communist Central European) system be analyzed through the lenses of existing conceptual apparatuses, produced to study a historically different set of systems? Our research question is whether the emergent, empirical quantitative picture of university governance and management in Poland, after a quarter of a century of large-scale changes, fits the traditional models conceptually developed to study

\footnotetext{
* Tel.: +48 618292280.

E-mail address: kwiekm@amu.edu.pl (M. Kwiek).
}

Western European and global higher education systems. Inparticular, we explore the issue of whether a collegial model of university organization fits the empirical patterns best, as the research literature (without empirical support, though) may indicate. The Polish system can be viewed as exemplary for other Central European postcommunist systems, with similar histories in the whole postwar communist period and similar social and economic challenges following the collapse of communism in the region.

Our point of departure is that the following observation from Gary Rhoades' chapter on governance models (in Burton Clark and Guy Neave's Encyclopedia of Higher Education) may no longer be true for European higher education systems:

Unfortunately, there is little research on the extent to which "models" of governance represent the "beliefs and behaviors" of people in the higher education governance structure (Rhoades, 1992, p. 1377, emphasis mine).

Rhoades' "models" and "beliefs and behaviors" of European academics can already be systematically comparatively studied 
through rigorously collected primary quantitative data today. This paper is based on large-scale internationally comparable quantitative material. Its empirical evidence comes from about 3700 returned surveys in Poland (and more than 17,000 in eleven European countries) produced for two international research projects focused on the academic profession (CAP: "Changing Academic Profession" and EUROAC: "The Academic Profession in Europe"). The national data relating to views, attitudes and behaviors open up a huge potential for the cross-national comparative analysis of the governance models/beliefs and behavioral dynamics we are focusing on in the Polish case. Consequently, the traditional university governance models, functioning as Max Weber's ideal types, can be measured against large-scale comparative material collected across higher education systems in Europe.

The paper is structured as follows: this introduction is followed by a section on the analytical framework (with subsections on university governance, university governance models, and academic collegiality), followed by a section on methodology and data. The next section on empirical findings analyzes descriptive statistics and several specifically constructed indexes (Index of Government Influence, Index of Academic Entrepreneurialism, and Index of Collegiality), presented from a European quantitative comparative perspective. This is followed by a brief section with the conclusions.

\section{Analytical framework}

\subsection{University governance}

In higher education research, university governance is viewed from both broader (for example, Huisman et al., 2008; Neave and van Vught, 1994; Amaral et al., 2009) and narrower perspectives (for instance, Shattock, 2006; Tight, 2012). Governance from a broader perspective refers to the changing relationships between the university and the state or to a new "social contract" (Maassen and Olsen, 2007); especially in such recent contexts as globalization and Europeanization as challenges to nation-states and welfare states, the changing role of public and private sectors in the provision of social services, and the growth of markets/quasimarkets in higher education.

In these broad contexts, such concepts as the rise of the "evaluative state" or "steering at a distance" have emerged in higher education research (Neave, 2012; Neave and van Vught, 1991). In the "triangle of coordination" between higher education institutions and academics, the state, and the market in Continental Europe, the policy changes "were mostly formulated as a recalibration of the powers of governments versus the higher education institutions. Only in the 1990s ... the concept of market mechanisms became more dominant it the policy and steering debates" (Huisman, 2009, p. 3). As Magalhaes and Amaral (2009, p. 87) argued, the changing relationships between states and higher education systems meant that "states have started to promote an apparent deregulation - by inducing institutions to go to the market, to self-regulation and to competition between themselves - as a more efficient form of regulation". Consequently, from a broader perspective, the "search for a new pact" between universities and society is in progress (Maassen and Olsen, 2007, p. 181).

From a narrow perspective, in contrast, "university governance is defined as the constitutional forms and processes through which universities govern their affairs. ... governance extend[s] right through senates and academic boards to faculty boards and departmental meetings" and governance is effective when "these levels of governance work together productively" (Shattock, 2006, p. 1). It is a perspective shared by the "how to" literature on the management of academic institutions and by those studies on leadership that focus on senior management roles (Tight, 2012, pp. 132-135). In various parts of our analysis, we refer to both approaches. In studying collegiality, we take a narrow view of governance because we focus on micro- and meso-level academic phenomena. But in the operationalization of Johan P. Olsen's visions of the university, we take a broad approach to governance, going beyond the micro-level of individual academics and the meso-level of institutions to the macro-level of state-university relationships.

In particular, taking a broad approach, we were interested in the "less state" and "more market" simplification of New Public Management ideas relating to universities across Europe. What is termed "the governance analytical perspective" provides a "general analytical framework for studying all kinds of coordination problems among actors" (de Boer et al., 2007, p. 138). Following the analysis of the governance of university systems in England, the Netherlands, Austria and Germany proposed by de Boer et al. (2007), we took a bird's eye view of Polish universities using the five dimensions: "state regulation" (top-down authority), "stakeholder guidance" (intermediary bodies as goal-setters and advisers), "academic self-governance" (as institutionalized in collegial decision-making at universities), "managerial self-governance" (university leadership as internal goal-setters, regulators and decision-makers), and "competition for scarce resources" (mostly on "quasi-markets"). De Boer et al. (2007) argue that "a configuration of governance is made up of a specific mixture of the five dimensions at a particular point of time" (2007: 139). Looking at the last decade of changes in Polish universities, we concluded that state regulation is high and on the rise, but managerial self-governance, external guidance, and competition are low and on the rise. And academic selfgovernance is high and only beginning to decrease. Consequently, the Polish picture is only beginning to resemble the Western European picture (in terms of directions of changes in the university governance configuration) as studied in the four countries, and the major difference is the current exceptionally high level of academic self-governance. In our study, we take a cross-national comparative analysis to a different level, indeed "stepping down even further to the micro-level of the day-to-day work of individual academics and research groups" (de Boer et al., 2007, p. 150). To assess the Polish case, we refer to both narrow approaches to university governance (as both Robert Birnbaum and Ian McNay focus on intra-institutional academic phenomena in their conceptualizations) as well as to broad approaches to it (as Johan P. Olsen focuses on both intrainstitutional meso-level and macro-level academic phenomena). In our conceptual framework, both approaches are viewed as complementary.

\subsection{University governance models}

University governance has been understood in organization theory through different "cognitive frames" (Birnbaum, 1988, p. 84), "images" and "metaphors" (Morgan, 1986), and "models" (Clark, 1983). Following Robert Birnbaum, we view a model as "an abstraction of reality that, if it is good enough, allows us to understand (and sometimes to predict) some of the dynamics of the system that it represents. Models are seldom right or wrong; they are just more or less useful for examining different aspects of organizational functioning" (Birnbaum, 1988, p. 83). And following Charles A. Lave and James G. March in their Introduction to Models in the Social Sciences, we view a model as "a simplified picture of a part of the real world. It has some of the characteristics of the real world, but not all of them. It is a set of interrelated guesses about the world" (Lave and March, 1993, p. 3). 
Polish (as well as Central European) universities had not been researched at the time currently prevalent Western European and American models of university governance were being developed due to the political and scientific isolation of this part of Europe during the communist period (it was exactly the same regarding welfare state comparative research - traditional welfare state models did not refer to this part of Europe). Working with typologies is useful in mapping the contours of institutional and systemic changes, especially in the context of a post-communist country with its social institutions still in transition. A study of the empirical data makes it possible to position Poland among other European systems and to assess its higher education against existing models of university organization and governance.

We found three such typologies of university governance useful in the present study: they come from Robert Birnbaum, Ian McNay and Johan P. Olsen. Birnbaum(1988: 83-174) distinguished between four major models of academic organization: "collegial", "bureaucratic", "political”, and "anarchical”. McNay (1995, pp. 105112) presented four models of university organization which coexist in time with different balances among them: "collegium", "bureaucracy”, “corporation”, and "enterprise”. And Olsen (2007, p. 30 ), in turn, argued for four "stylized visions" of the university: "a rule-governed community of scholars", "an instrument for shifting national political agendas", "a representative democracy", and "a service enterprise embedded in competitive markets".

We analyzed organizational patterns in Polish higher education as seen through new, complex international empirical data. We did not construct a new typology: we assessed the applicability of selected existing typologies to real patterns of functioning for Polish universities (as the analyzed typologies and models refer to universities, we restricted our empirical data to universities rather than to the whole higher education system). In particular, we explored the question as to what extent the reality of the Polish system fits the academic collegial models presented by Olsen, Birnbaum, and McNay. Olsen's institutional model of the university as a "community of scholars" (in principle, parallel to Birnbaum's and McNay's "collegium" models) is empirically tested below. It is also briefly empirically contrasted with his instrumental models of the university, particularly the model of the university as an "instrument for shifting political agendas" which is growing in importance in Poland in this time of massive higher education reforms.

We had two approaches to choose from: either to examine in very general terms as to what extent traditional university governance typologies and models are applicable in Polish universities (focusing on Olsen, Birnbaum, and McNay); or to focus on a specific governance model present in the three typologies (that is, the collegial model) and test the initial assumption that this model may fit the Polish case best. We followed the "testing" approach for a collegial model, following an initial assessment, based on a study of the research literature, that Poland may manifest the features of a "community of scholars" model much more strongly than most other European systems (together with Portugal and Italy, defined as "professorially coordinated systems" by Teichler et al., 2013, p. 191).

A review of the research literature on university governance in Poland clearly shows that from among Burton Clark's three distinctive patterns of coordination (coordination by senior academics, coordination provided by the state, or coordination signaled by the market), the coordination by senior academics and the collegial bodies in which they are dominant is prevalent. Following the collapse of communism, the Humboldt-oriented model was an expression of the deep aversion to state and external intervention and offered the academic community what Dobbins and Knill (2009, p. 424) termed "the best of both worlds": "the state continued to finance HE in full but remained nearly powerless with regard to teaching, research, administration, and procedural matters. This enabled academics to establish institutions of 'academic democracy' while maintaining their state funding base". Autonomy in Polish universities, linked to the collegial model of university governance in the three typologies, is construed as "delegating all authority to collegial bodies", with the threat that "locating too much authority in the collegial bodies (the senates and the faculty boards) could restrict the autonomy of the institution as a whole" (Białecki and Dąbrowa-Szefler, 2009, p. 197; see Kwiek, 2009a). As these authors comment, autonomy in the version professed by the Polish academic community "is often construed as independence from the expectations and aspirations of the professional communities corresponding to the academic disciplines" (2009: 197). In a similar vein, Dobbins (2015, pp. 24, 25) stresses that Poland is maintaining "most features typical of academic self-rule" and is "relatively insulated from socioeconomic stakeholders". After the collapse of communism in 1989, universities became fully autonomous institutions and decision-making power returned to "high-ranking academics who governed by means of academic senates" (Dobbins, 2015, p. 24). The Polish government until the mid-2000s was weak in pursuing its policy goals, being primarily interested in ever-rising enrolments and trying to limit the negative influence of multiple employment among academics (Pinheiro and Antonowicz, 2014; Kwiek, 2003; Kwiek, 2012). A World Bank report (World Bank/EIB, 2004, pp. viii-ix) stated that Polish universities had higher levels of autonomy than universities anywhere else in Europe and this autonomy was not counterbalanced by accountability to the government and other stakeholders. Also, another international report on Poland concluded that "institutional management and governance are weak; central government lacks sufficient tools to steer the system and institutions" (Fulton et al., 2007, p. 117). Therefore, we wanted to test the collegial model as a probable candidate that fits the Polish case well.

\subsection{Academic collegiality}

Following Birnbaum (1988) and adapting his four major models of university organization (collegial, bureaucratic, political, and anarchical), Kathleen Manning in her Organizational Theory in Higher Education defines the collegial model of university organization through such features as circular communication and consensus decision making, leadership as first among equals, the socialization of new faculty members, academic freedom, tenure, and self-governance or a system of shared governance to make collective institutional decisions (Manning, 2013, pp. 40-48). Most of these features can be studied though variables within our dataset.

Birnbaum's defines a "collegial system" through the following characteristics:

An emphasis on consensus, shared power, common commitments and aspirations, and leadership that emphasizes consultation and collective responsibilities are clearly important factors ... It is a community in which status differences are deemphasized and people interact as equals, making it possible to consider the college as a community of colleagues in other words, as a collegium (Birnbaum, 1988, pp. 86-97).

A "collegium" as Birnbaum defines it is a collegium of senior, tenured academics (the non-tenured class of assistants not seeming to belong to it, as we shall show in the section on empirical findings). Much of the interaction between them is informal, the institution is egalitarian and democratic, and members of the administration and faculty "consider each other as equals"; there is an emphasis on "thoroughness and deliberation", and decisions are being made by consensus; the administration is understood to be "subordinated to the collegium and 
carries out the collegium's will"; administrators tend to be "amateurs" rather than professionals; the leader is elected rather than appointed and he or she is not seen by faculty as a "boss" but rather as "first among equals"; there is "general agreement on the expected and accepted relationships" between administrators and faculty; informal norms control academic behavior more powerfully than do written rules and regulations; and leaders are selected by their colleagues because they believe leaders exemplify their institutions' norms (Birnbaum, 1988, pp. 87-101).

Similarly, Ian McNay links his model of "collegium" to one of the four of Clark (1983, pp. 247-249) "basic values" in higher education, namely "liberty" or "freedom". The role of central authorities in this model is "permissive", its management style is "consensual", the role of administration is to be the servant of the academic community and the timeframe in organizational thinking is "long" (McNay, 1995, p. 109). Collegiality, as Clark (1987, p. 384) notes in a similar vein, is "the form of authority about which the profession expresses the greatest pride. It has democratic, anti-bureaucratic overtones, as decisions are to be made not by a boss by a group of peers; equality is operationalized in a one-person one-vote procedure". The "collegial model" of academic governance, as Gary Rhoades summarizes it:

emphasizes nonhierarchical, cooperative decision making and the significance of faculty self-determination. Various campus constituencies are knit together by common interests and by a sense of academic community that legitimizes the concerns of these parties. Members of that community participate collegially in administering the affairs of the organization. The concerns of the faculty are particularly influential in the process of academic self-governance (Rhoades, 1992, p. 1377).

Finally, Johan P. Olsen presents four models, or "stylized visions", of university organization and governance (Olsen, 2007, pp. 28-33) which generally coexist in time, being "enduring aspects of university organization and governance. The mix of visions varies over time and across political and cultural systems". As he notes:

if support is conditional and a question of degree and the four visions are both competing and supplementing each other, there will in some periods and contexts be a balance among the different visions. In other periods and contexts one vision may generate reform efforts, while others constrain what are legitimate and viable solutions (Olsen, 2007, pp. 36-37).

The initial assumptions of this study, based on the research literature, were that there may be some incommensurability between the values shared by two communities: the Polish academic community and the Polish policymaking community. Polish academics may be strongly embedded in Olsen's first model of university organization ("a rule-governed community of scholars") and the Polish policy-making community may be heavily involved in implementing his second model of university organization ("an instrument for shifting national political agendas"). The general rejection of the direction of ongoing reforms by large segments of Polish academia in 2010-2013 may be a reflection of a fundamental incommensurability regarding the guiding principles believed to drive Polish universities. The above rejection may be the result of a clash between two university models and university visions. These initial assumptions were confirmed by the detailed empirical analyses which follow.

In the section on "Findings", we first assess the applicability of Olsen' s first model. Then we present an "Index of Government Influence" and an "Index of Academic Entrepreneurialism" as two different operationalizations of Olsen's second model. And then we discuss collegiality through the operationalization of Birnbaum's and McNay's models of "collegium" (specifically, to assess Poland in a European comparative context, we construct an "Index of Collegiality" showing the relative power of academic collegial bodies among other academic actors involved in making academic decisions).

The analytical power of the three indexes lies in their relative nature: the relative ranking of the Polish higher education system among other European systems is more important than the absolute values of these indexes. We aggregate, average and produce the indexes for specific countries based on the percentages of academics agreeing or strongly agreeing with selected statements (in some cases, in reverse scale order). Indexes are therefore derived directly from the statistics on the views of the academic profession. Thus, for instance, European systems can be assessed as more or less "collegial" or more or less "entrepreneurial", or more or less "market-like" according to academic perceptions (that is, perceptions internal to academic institutions rather than according to - external to institutions - national or institutional statistics).

Such an internal perspective reveals a state of affairs in higher education often hidden behind the data aggregated to the level of the state, the higher education sector or its institutions. The microlevel perspective of individual faculty members is useful for all higher education stakeholders: either as their self-knowledge, or as an aid in understanding institutions subject to unprecedented, long-term reform pressures. Especially that academic communities and policy-making communities in Poland seem to fundamentally differ in their views about which models of university organization are most desirable for the future.

In general, we explore the issue as to what extent the theoretical models of university governance produced in Western European and American research literature fit the reality of the Polish system; that is to say, to what extent these models fit the empirically studied (Rhoades) "beliefs and behaviors" of the Polish academic profession. And in particular, we test the hypothesis that a collegial model fits the Polish case best. The answers in this paper are only contextual and relative: we position Polish universities in the context of universities from ten other Western European countries.

\section{Methodology and data}

In principle, there are three research designs to assess the applicability of various theoretical university governance models to the reality of Polish universities (or three approaches to contrasting the "models" produced in one set of national contexts with the "beliefs and behaviors" from another context): a continuum between more quantitative, mixed methods, and more qualitative research designs (Creswell, 2009). Our approach is more quantitative but the qualitative material collected in six countries (the EUROAC project countries: Croatia, Finland. Germany, Ireland, Poland, Switzerland) could also be useful. Although we decided not to refer directly to the qualitative material available, our study is indirectly underpinned by about 500 interview reports based on semi-structured in-depth interviews with academics which followed a common interview protocol, and especially in 60 in-depth interviews with Polish academics conducted in 2011 by Dr. Dominik Antonowicz (for comparative analyses mostly based on qualitative material, see Fumasoli et al., 2014 and Kwiek and Antonowicz, 2015). The decision was grounded in methodological assumptions: a more quantitative approach suits the exploration of our research questions best, especially that the qualitative material is available for only five out of the eleven countries studied. ${ }^{1}$

\footnotetext{
${ }^{1}$ We left out the data on the small system of Croatia because the number of responses did not reach the initially assumed threshold for both CAP and EUROAC projects, $800-1000$ per country.
} 
The data used in this study are drawn from eleven European countries involved in both the CAP and EUROAC projects (Austria, Finland, Germany, Ireland, Italy, the Netherlands, Norway, Poland, Portugal, Switzerland, and the United Kingdom), subsequently cleaned and weighted in a single European dataset by a University of Kassel team. ${ }^{2}$ The combined CAP/EUROAC dataset is the most comprehensive source of cross-national attitudinal and behavioral data on academics available today (see the wide panorama of research themes explored with this dataset as an empirical background in the last three years: Shin et al., 2014 on "teaching and research"; Locke et al., 2011 on "governance and management"; Huang et al., 2014 on "internationalization"; Teichler and Höhle, 2013 on "work situation"; Bentley et al. on "job satisfaction"; and Teichler et al., 2013 on "the changing academic profession"; from a long list of cross-national and single-nation studies available). In particular, our study is empirically based on the single biggest cross-national source of data on academic views, attitudes and perceptions. The quality of data is high (Teichler et al., 2013, p. 35; Teichler and Höhle, 2013, p. 9), as is the relevance of the dataset for the present study. Although the research question on the theoretical models of university governance applied to the Polish case could have been pursued based on other data sources (e.g. through secondary data analysis), our research has followed what is perceived as the "gold standard" of social science research design: primary data collection analysis (Goodwin, 2012: xxi). We follow Locke (2011), p. 381) who argued that the dataset in question is a "unique source for examining the Academy's perception of governance and management in a comparative perspective".

The survey questionnaire was sent out to the CAP countries in 2007 and to the EUROAC countries in most cases, including Poland, in 2010 (this time difference is viewed here as of marginal importance to the final results). The total number of returned surveys was 17,212 and included between 1000 and 1700 returned surveys in all countries studied except for Poland where it was higher, as shown in Table 1 below. Overall, the response rate differed from over 30 percent (in Norway, Italy, and Germany), to 20-30 percent (in the Netherlands, Finland, and Ireland), to about 15 percent in the United Kingdom, 11 percent in Poland and 10 percent or less in Austria, Switzerland and Portugal. Relatively low response rates may be caused by the increasing number of surveys to which the academic profession is routinely exposed (Mesch 2012, p. 316 ff.). There are no indications that the pool of respondents differs from the pool of non-respondents, though, and consequently the "non-response bias" (Stoop, 2012, p. 122) does not seem to occur. The Polish subsample of 3704 academics is a special case: it is highly representative of the population of about 79,000 Polish academics, even though the response rate for Poland was 11.22 percent. Overall, simple random sampling, systematic sampling, and stratified random sampling methods were used, depending on the country. In Poland, we used the sampling method of an "equal probability of selection method" (Hibberts et al., 2012, p. 55): every element in a sample (every Polish academic) had an equal chance of being selected for the study (performed by the national research institute OPI, or the Center for Information Processing), with individualized invitations to participate in the survey sent to about 39,000 academics, or all academics whose e-mail addresses were available at a central level. In contrast, in Germany, Switzerland and Austria, cluster sampling methods were used, with a pre-selection of some institutions. In the process of international data coordination,

\footnotetext{
${ }^{2}$ We worked on the final dataset dated June 17, 2011 and created by René Kooij and Florian Löwenstein from the International Centre of Higher Education and Research - INCHER-Kassel, Germany.
}

Table 1

Sample characteristics, by country.

\begin{tabular}{|c|c|c|c|c|c|}
\hline & $N$ & $\begin{array}{l}\text { Universities }\left({ }^{*}\right) \\
\%\end{array}$ & $\begin{array}{l}\text { Other HEIs } \\
\%\end{array}$ & Full-time & Part-time \\
\hline Austria & 1.492 & 100.0 & 0.0 & 65.8 & 34.2 \\
\hline Finland & 1.374 & 76.5 & 23.5 & 82.4 & 17.6 \\
\hline Germany & 1.215 & 86.1 & 13.9 & 70.7 & 29.3 \\
\hline Ireland & 1.126 & 73.3 & 26.7 & 91.2 & 8.8 \\
\hline Italy & 1.711 & 100.0 & 0.0 & 96.9 & 3.1 \\
\hline Netherlands & 1.209 & 34.4 & 65.6 & 56.0 & 44.0 \\
\hline Norway & 986 & 93.3 & 6.7 & 89.7 & 10.3 \\
\hline Poland & 3.704 & 48.3 & 51.7 & 98.0 & 2.0 \\
\hline Portugal & 1.513 & 40.0 & 60.0 & 90.3 & 9.7 \\
\hline Switzerland & 1.414 & 45.6 & 54.4 & 58.5 & 41.5 \\
\hline UK & 1.467 & 40.8 & 59.2 & 86.5 & 13.5 \\
\hline
\end{tabular}

*In Austria and Italy, there was no distinction between "universities" and "other higher education institutions" in the sample.

sample weights were made by the Kassel statistical team; sample values were weighted to reflect the actual parameters of the academic profession in the countries studied. For the purposes of the current research, basic frequencies were computed on selected items from the weighted dataset; with cross-tabulations of selected dependent variables being computed against certain independent variables (especially: academic field cluster, institutional type, age, and career stage).

From a full weighted sample of 17,211 cases across 11 countries, the study analyzed only the subsamples of full-time academics $(13,633)$ and academics working in universities $(10,777)$ rather than in any "other higher education institutions". We have excluded part-timers to avoid distortions to the picture: the share of part-time academics in the sample is too differentiated, from 23 percent in Poland and Italy to more than 40 percent in the Netherlands and Switzerland. "Universities" were defined by national research teams. Consequently, data are drawn from about $9000(N=8886)$ cases. The study is focused on Polish academics employed full-time in "comprehensive universities" (rather than in so-called universities "with adjectives", such as e.g. universities of economics, polytechnics and "other higher education institutions"). In Europe, our study is focused on full-time academics in the UK from the Russell Group, and in Finland from universities rather than polytechnics; similarly, in the Netherlands we have excluded academics from hogescholen, in Germany academics from Fachhochschulen, and in Norway from statlige høgskoler; only in Italy and Austria did we focus on all full-time academics as no other institutional types were represented in the sample.

Individual data files were produced in all participating countries, but all specifically national categories (faculty rank structures, institutional type structures etc.) were reduced to internationally comparable categories. An international codebook was created and a number of coding modifications were introduced into national data files, in particular the dichotomization of all faculty into "senior" and "junior" faculty and into faculty employed in "universities" and those employed in "other higher education institutions". The data cleaning process included the use of "survey audits" prepared by national teams. In the process of international data coordination, sample values were weighted so that the national samples in the countries studied were broadly representative of national academic populations for most independent variables, especially gender, academic fields, institutional types and institutional ranks (national-level sampling techniques are described for the CAP European countries in RIHE, 2008, pp. 89-178, and for the EUROAC countries in Ulrich and Höhle, 2013, pp. 6-9). All the problems and complexities of large-scale international collaborative empirical studies apply, though. The 
Table 2

Proportion of faculty by academic field cluster and sample size $(N)$.

\begin{tabular}{|c|c|c|c|c|c|c|c|}
\hline & Life sciences and medical sciences & Physical sciences, mathematics & Engineering & Humanities and social sciences & Professions & Other Fields & $\begin{array}{l}\text { Total } \\
(N)\end{array}$ \\
\hline Austria & 20.2 & 9.8 & 11.9 & 41.3 & 8.7 & 8.2 & 1.492 \\
\hline Finland & 15.7 & 9.7 & 21.5 & 18.6 & 12.1 & 22.4 & 1.374 \\
\hline Germany & 29.3 & 15.2 & 14.8 & 15.6 & 11.1 & 13.9 & 1.215 \\
\hline Ireland & 23.0 & 11.5 & 8.8 & 23.8 & 20.5 & 12.4 & 1.126 \\
\hline Italy & 28.6 & 23.3 & 11.1 & 17.5 & 13.6 & 5.9 & 1.711 \\
\hline Netherlands & 12.6 & 10.9 & 10.7 & 22.3 & 34.7 & 8.8 & 1.209 \\
\hline Norway & 29.0 & 14.1 & 7.4 & 27.5 & 8.9 & 13.1 & 986 \\
\hline Poland & 24.6 & 8.4 & 21.5 & 23.0 & 12.5 & 10.0 & 3.704 \\
\hline Portugal & 16.9 & 7.9 & 20.4 & 10.5 & 20.6 & 23.7 & 1.513 \\
\hline Switzerland & 30.8 & 10.2 & 12.7 & 16.9 & 23.9 & 5.5 & 1.414 \\
\hline UK & 21.9 & 11.6 & 6.3 & 18.6 & 11.0 & 30.7 & 1.467 \\
\hline
\end{tabular}

proportion of faculty by academic field cluster is given below in Table $2 .^{3}$

There is a list of limitations relevant to this study. The first of them is our inability to compare academic perceptions across academic generations: the cohort aspects of academic perceptions cannot easily be studied through cross-sectional datasets. Cohort effects mean that academics employed under different conditions and at different times are being inter-generationally compared at a given moment in time, and it is difficult to disentangle age effects from cohort effects. We can analyze various academics' perceptions, even in age brackets (e.g. academics in their 30s, 40s, 50s, and 60s), but they still belong to different academic generations. This is clear from our study of the junior-senior split in Polish academia presented below. The second limitation is our inability to compare academic perceptions across individual institutions but only between large clusters of them. What has often been referred to in the research literature as the "colleague climate", the encouragement of research, reflected in institutional prestige and linked to our notions of collegiality (Blau, 1994, p. 238; Finkelstein, 1984, p. 97), cannot be studied on a per-institution basis through our dataset because the anonymization of the collected data precludes any links between individual academics and individual institutions. We are therefore unable to study differences in academic perceptions of collegiality between academics from institutions of lower academic standing and those from the most prestigious ones (all we could do was to distinguish between a broad cluster of "universities" and a broad cluster of "other higher education institutions" in each system studied).

The third limitation is closely related to cross-national analyses of higher education systems. While in the last few years the field of (applied) higher education research relied significantly on crossnational studies (apart from single-nation studies), potential caveats may be more relevant for Poland than for any other European country studied in this paper. Our research results presented elsewhere indicate that Poland may differ more from the cluster of ten Western European countries than any two countries from within the cluster (see Kwiek, 2015a on the role of "internationals" and "locals" in knowledge production across Europe, and Kwiek, 2014a - in Poland, and Kwiek, 2015b on the role of the most highly performing academics and non-performing academics across Europe). It is, for instance, very difficult to

\footnotetext{
${ }^{3}$ We studied five major academic field clusters: "life sciences and medical sciences" (termed "life sciences" and "medical sciences, health-related sciences, social services" in the survey questionnaire), "physical sciences and mathematics" ("physical sciences, mathematics, computer sciences"), "engineering" ("engineering, manufacturing and construction, architecture"), "humanities and social sciences" ("humanities and arts" and "social and behavioral sciences"), and "professions" ("teacher training and education science", "business and administration, economics", and "law").
}

classify Poland within the existing and emergent typologies of systems in terms of predominant role orientation (teaching/ research). Jung Cheol Shin, Akira Arimoto and William K. Cummings in the organization of their recent book based on the CAP data (2013) presented a typology consisting of "research focused systems" (all Continental European systems studied), "teaching focused systems" (Mexico, Brazil, Argentina, Malaysia, and South Africa), and "teaching and research balanced systems" (the USA, Canada, the UK and Australia). In a parallel formulation, a distinction is drawn between "emergent" and "mature" higher education systems, where all "emergent" systems are "teaching focused systems" (Locke et al., 2011). Where should Poland be located in our solely cross-European study in the above typologies? Does Poland differ so much in its teaching and research behaviors and attitudes that it should be lumped together with nonEuropean ("teaching focused" and "emergent") systems, despite clearly historically belonging to the European, Humboldtian family of university systems? Is Poland, based on data collected in a comparable format, distinct enough not to be included among the Continental European family of systems? The provisional answer is that Polish higher education is rapidly changing towards a highly stratified system with a small number of research-intensive universities which attract the bulk of all the research funding available and the vast majority of increasingly teaching-focused institutions, with limited access to ever more competitive research funding (see Kwiek, 2014b).

The above uncertainties about where Poland belongs (and where it does not belong) in recently emergent international typologies are linked to the uncertainties born out of the way we try to answer our question regarding the applicability of governance models to the Polish empirical case. Our analysis is rooted in the tacit assumption that the major concepts used across all the eleven systems in the survey instrument have a somewhat similar meaning: the concepts which are embedded in our study include "scholarship", "academic knowledge", "professional obligations", "primary research”, “commercial orientation”, “external sponsors and clients", "performance based allocation of resources", "entrepreneurial activities", "setting internal research priorities", "determining budget priorities", and "evaluating research". A clear limitation of the study is that there may not only be different senses of these terms used in academic perceptions between all the countries, but even more so - between Poland and the ten comparator countries studied. Such limitation is emphasized by Daniel, 2000, 219) in his cross-national study of research productivity, which reveals the potential danger of "applying the findings of Western literature on publication productivity to other national contexts. It is clear from these findings that a common model of publication productivity cannot be assumed to operate in different national contexts since many variables are context specific". We assume that a quarter of a century after the collapse 
of communism, the concepts are more similar in Poland and the ten European countries than ever before.

Finally, there are two major missing systems in this paper: the French and the Spanish. Also, other Central European systems for which no data are available in a comparable format have not been analyzed. But this is a problem for many cross-European studies based on primary data and we have decided to rely solely on a coherent European dataset rather than to refer selectively to secondary data (collected in incomparable formats).

\section{Findings}

4.1. Polish universities and the institutional vision of the university: a "rule-governed community of scholars"

We start our analyses with the question of the applicability of Olsen's first model to the realities of Polish universities: this model is the university as "a rule-governed community of scholars" (related to Robert Birnbaum's "collegial" model; J. Victor Baldridge's "university collegium"; Ian McNay's "collegium"; and Bleiklie and Kogan's (2007) “republic of scholars”). The university in this model is an institution with the following characteristics, which we will link below to selected variables from our European dataset: it has its own constitutive and normative and organizational principles; it shows a shared commitment to scholarship and learning, basic research and the search for the truth (irrespective of immediate utility and applicability, political convenience or economic benefit); it is supposed to benefit society as a whole and not specific "stakeholders" or those able to pay; neutral competence is the only source of legitimate authority; it shows collegial organization, has elected leaders and a disciplinary organization; its activities and results are assessed by the internal norm of scholarship (peer review); truth is an end in itself, and the system evolves through internal, organic processes (rather than external design) (Olsen, 2007, pp. 30-31). ${ }^{4}$

Our research question is to what extent do Polish universities manifest the characteristics of Olsen's model? We link Olsen's ideas presented above to selected variables to see how the Polish system can be located among other European systems. Based on the research literature, the initial hypothesis is that Poland should be a "community of scholars" type of system to a higher degree than most European systems. In particular, we assume that the current dynamics of changes is as follows: the collegial model is powerful today but it may be slowly eroding in the face of ongoing structural reforms.

Here we analyze five statements from the dataset best fitting Olsen's first model with views on the following: scholarship and research, the character of the primary research being done, and research funding. Not all the parameters of the model are reflected in the dataset but at least five statements are directly linked to Olsen's ideas. The five statements analyzed here are the following (percent "agreeing" means the percentages for answers 1 and 2 are combined. A five-point Likert scale was used: from $1=$ strongly agree to $5=$ strongly disagree and from $1=$ very much to $5=$ not at all, depending on the question; full-time faculty employed in universities only):

- "Scholarship includes the application of academic knowledge in real-life settings" (B5/2): Poland, together with Austria, ranks the lowest (59 percent agreeing vs. a European average of 74 percent).

\footnotetext{
${ }^{4}$ See also two classical statements on the ideal of the university as a "community of scholars" published half a century ago: John D. Millett's The Academic Community. An Essay on Organization (Millett, 1962, pp. 66-105); and Paul Goodman's The Community of Scholars (Goodman, 1962, pp. 84-106).
}

- "Faculty in my discipline have a professional obligation to apply their knowledge to problems in society" (B5/8): Poland ranks the lowest (40 percent agreeing vs. a European average of 57.3 percent).

- "Emphasis of your primary research: applied/practically oriented" (D2/2): Poland ranks the lowest (45.5 percent very much vs. a European average of 60.9 percent).

- "Emphasis of your primary research: commercially oriented/ intended for technology transfer" (D2/3): Poland ranks the lowest (9.8 percent very much vs. a European average of 15.4 percent).

- "External sponsors or clients have no influence over my research activities" (D6/3): Poland ranks very high as the third from the top, following Norway and Austria (59.6 percent agreeing vs. a European average of 53.5 percent).

Thus the Polish system differs substantially from most European systems in most of the items related to the Olsen "community of scholars" model studied. It ranks the lowest in Europe in several categories in which the lower the rank, the closer the system id to the model. Poland is also ranked third from top in the lack of influence of external sponsors on research (the higher the rank, the closer a system is to the model studied). Although the emergent picture of Polish universities could be shown only through a limited number of parameters from the Olsen model (because of the limited number of relevant dataset variables), from among all European countries analyzed, Poland is the closest to it.

Most of all, though, Polish universities turn out to be institutions isolated from both the needs of society and the needs of economy, and are closer to the ideal of the Ivory Tower than any other European system studied. This is based on academics' beliefs which are crucial to academic performance (along the same lines Poland has been criticized by international reports on higher education published in the last few years by the World Bank and the OECD). This disappointing picture is shown by institutional and national higher education as well as research and development statistics (through such parameters as total income from industry or the share of income from industry in total income, either on a national scale or at the level of the operating budgets of particular institutions). And the same picture - in a complementary manner is confirmed through an analysis of the views and beliefs shared by the Polish academic profession, in a relative and contextual manner: compared with the other ten systems studied. There does not seem to be any necessary link between academic collegiality, understood in the sense of universities functioning as "communities of scholars" (and, as we shall show further in this paper, understood in the sense of the uncommon role of elected academic bodies) and the limited professional connectedness between universities and the external social and economic world. Collegiality does not anywhere in Europe mean the separation of universities from the outside world, and especially separation from the economy. The Polish case seems to show that an uncommonly high level of interiorization by the academic profession of traditional academic norms, historically associated with the ideal of the Ivory Tower, goes hand in hand with an uncommonly low level of readiness to professionally connect with the outside world.

\subsection{Polish universities and an instrumental vision of the university: an "instrument for shifting political agendas"}

In Olsen's second model of the university (the university as an "instrument for shifting national political agendas"), one of his three instrumental models, the university is viewed as:

a rational tool for implementing the purposes and policies of democratically elected leaders. It is an instrument for achieving 
national priorities, as defined by the government of the day. The University cannot base its activity on a long-term pact based on constitutive academic values and principles and a commitment to a vision of civilized society and cultural development. Instead research and education is a factor of production and a source of wealth or welfare. The University's purposes and direction of growth depend on shifting political priorities and funds more than on scholarly dynamics. A key issue is applicability and utility of research for practical problem-solving, such as defense, industrial-technological competition, health and education. ... Change in the University is closely linked to political decisions and change (Olsen 2007, p. 31).

While today this model can be clearly viewed as very weak in Poland on empirical grounds, it is the model powerfully promoted (mostly at the discursive level) by the international community of experts appealing to such umbrella terms as the "knowledgedriven economy"; this model is also strongly promoted by the policy-making community in a recent wave of higher education reforms in Poland, heavily influenced by the OECD report on Poland, swiftly translated into Polish (see Fulton et al., 2007). This is the model for the policymaking community in the current reform period.

We translate the model into variables found in our dataset (not all aspects of the model described above can be viewed through the available variables but at least two aspects can be analyzed in more detail: government influence on academic decisions and on academic entrepreneurialism). Then we assess the applicability of Olsen's second model to the Polish case through two composite indexes: a high rank for Poland in the "Index of Government Influence" and a high rank in the "Index of Academic Entrepreneurialism" would mean a good fit between this model and the current Polish academic reality. The ranking of Poland in both indexes clearly shows that Polish academics do not perceive Olsen's second model as important, compared with academics in other European systems, though (see also Kwiek, 2009b).

Poland ranks by far the lowest in Europe in the "Index of Government Influence": the index is the aggregated and averaged value of answers to the question "At your institution, which actor has the primary influence on each of the following decisions?" (E1); with answers to indicate "Government or external stakeholders". The various options to choose from were "institutional managers", "academic unit managers", faculty committees/ boards", "individual faculty" and "students" (a list of all the eleven decision making contexts studied is shown in Table A1 in the Data Appendix). What is important here is not the absolute index values for particular countries but the relative rank of Poland among the other systems studied: for Poland, the composite index is by far the lowest. In other words, the influence of the government (and "external stakeholders") on the functioning of universities in the eleven aspects selected for cross-national analysis, is very small; and certainly the lowest in Europe. The only significant difference in this index is that between Germany and all other countries, and between Poland and all other countries. Poland is slightly above the European average in only two academic contexts: faculty promotions and determining budget priorities; in all others, it is either the lowest, or one of the lowest. ${ }^{5}$

Also, in the second composite index linked to the second Olsen model of university organization - the "Index of Academic Entrepreneurialism", shown in Table A2 in the Data Appendix Poland ranks as the second lowest in Europe (followed only by Italy). This index is composed of the following five items, usually linked with academic entrepreneurialism in the research literature (Kwiek, 2013a): "performance based allocation of resources to academic units", “considering the practical relevance/ applicability of the work of colleagues when making personnel decisions", "recruiting faculty who have work experience outside of academia", "encouraging academics to adopt service activities/ entrepreneurial activities outside the institution" and "encouraging individuals, businesses, foundations etc. to contribute more to higher education" (for question E6, "To what extent does your institution emphasize the following practices?", the percentages for answers 1 and 2 are combined. A five-point Likert scale is used from 1 = "very much" to 5 = "not at all"). Polish institutions do not emphasize academic entrepreneurialism as viewed through the above five dimensions. The index is the highest for Germany, followed by a cluster of three countries: Finland, the Netherlands, and the United Kingdom.

The conclusion to be drawn from our brief analysis of the two composite indexes related to Olsen's second model of the university (the university as an "instrument for shifting national political agendas") is that this model does not seem to fit the realities of the Polish higher education system as perceived by Polish academics. Compared to other European systems, it is perceived by Polish academics as being the least applicable. But a detailed analysis of the Polish 2005-2012 (and especially 20082012) reform agenda shows that this is the dominating model at the level of official reform justifications and among the policymaking community. A clash between the two divergent university visions in the coming years may therefore be unavoidable, leading to a potentially increasing backlash on the part of the academic community to ongoing and further reforms. At the same time, new funding and governance instruments may fit Polish academic perceptions of what European higher education is, and be increasingly viewed as a "return to (European) normal", with more mechanisms at work for accommodation rather than protest.

The emergent conflict between the vision of the university shared by the academic community (the value-based, autonomydriven "community of scholars" model, the model most strongly supported in Europe by Polish academics) and the vision shared by the policy-making community (instrumental, externallydriven, extremely weakly supported by Polish academics) is a conflict about what Bowen and Schuster (1986, p. 53) term "basic values". Basic values are "derived from long academic tradition and tend to be conveyed from one generation to the next". While in the Western European systems analyzed in this paper this conflict between Olsen's institutional and instrumental visions (the university as a tool for different groups and purposes) has a history of several decades, following the reforms undertaken since the 1970s, in Poland this value-driven conflict is only beginning to emerge. The most collegial (and very much "professorially-coordinated") system in Europe is expected to be brought in line with other European systems through reforms, already increasingly driven by instrumental logic and involvement in an emergent "European higher education and research area", as well as also being driven by instrumental logic operating at the EU level.

Following both the Polish literature review and the results of preliminary data analysis (performed along the lines described above, with the same subsample of university academics but with different variables), we conclude that the remaining two of Olsen's

\footnotetext{
${ }^{5}$ The highest rank for Germany results from the impact of a single variable: "determining the overall teaching load of faculty"; which disappears if this variable is disregarded due to the specificity of the German system. Similarly, 0 percent for the variable "choosing new faculty" (in the Netherlands, Poland, and Portugal) requires an explanation: governments and external stakeholders in these countries do not have any influence on employment policy at the lowest, institutional level additionally, in the Netherlands and in the UK (more precisely in England) they do not have any influence on making faculty promotions; and in Norway, they have no influence on approving new study programs, as confirmed in the literature.
} 
instrumental models (the university as "a service enterprise embedded in competitive markets" and the university as a "representative democracy") do not fit the Polish case at all. ${ }^{6}$ Both Polish academics and the Polish policy-making community perceive them as largely irrelevant today.

To sum up: we argue that only Olsen's first, institutional and collegial model fits the Polish academic reality well today; as perceived by the academic community. However, the second, instrumental model - massively promoted in the new wave of Polish reforms though perceived as irrelevant by the academic community today - may gain influence over the coming years through various state-supported changes in funding and governance mechanisms (Kwiek, 2013b). In combination these models do not seem to complement each other in Poland, as Olsen describes the majority of Western European systems studied. The logic of current reforms dooms both models to be in powerful conflict, grounded in the incommensurability of traditional academic values and norms shared by the academic profession (as shown through a study of the composite indexes) on the one hand, and the values and norms promoted by higher education policymakers and reformers on the other. The political economy of reforms and the experiences of other European systems tend to show that in the coming years, academic values and norms may be gradually gravitating towards the second, instrumental model, promoted in subsequent waves of reforms, and away from the first, institutional model. In this way Polish higher education may be becoming ever less isolated from the problems of the outside social and economic world. At the same time, its organization and funding mechanisms will become fundamentally transformed.

\subsection{The perceived influence of various actors on university decision- making: "collegiality"}

In this subsection we analyze briefly a single issue: the perceived influence of various actors on university decisionmaking (already used above in the construction of the index of government influence). We are especially interested in the influence of traditional academic collegial bodies on a wide array of academic decisions. Academic collegiality in this part of the paper is understood, following Birnbaum (1988) and Ian McNay (1995), as the strong power of academic collegial bodies at the levels of faculties and departments. As McNay argues in his model of "collegium":

If the main tasks of the university are teaching and research, most developments will spring from these two activities and decisions will be based within the structures where they are organized - mainly discipline-based departments - within a frame of reference set by peer scholars in the international community (McNay, 1995, p. 106).

The power of academic collegial bodies is being contrasted in the survey instrument with the power of governments and external stakeholders, as well as institutional managers, on the one hand, and the power of academic unit managers and individual faculty members on the other. In the survey instrument, there was a choice of the following influential actors in the making of academic decisions: government or external stakeholders; institutional managers; academic unit managers; faculty committees/

\footnotetext{
${ }^{6}$ In the third model, the university is "an economic enterprise or a service station operating in regional or global markets. ... The University is governed and changed by its sovereign customers. Research and higher education are commodities, bundles of goods to be sold in a free market. Competition and achieving profit and other individual gains are key processes" (Olsen, 2007, p. 33). And in the fourth model, the university is an interest group democracy, with high participation of students and unions of employees (Olsen, 2007, p. 33).
}

boards; individual faculty; and students. ${ }^{7}$ The following eleven academic decision contexts viewed as the most essential at the stage of survey instrument design were studied in detail:

- Selecting key administrators.

- Choosing new faculty.

- Making faculty promotion and tenure decisions.

- Determining budget priorities.

- Determining the overall teaching load of faculty.

- Setting admission standards for undergraduate students.

- Approving new academic programs.

- Evaluating teaching.

- Setting internal research priorities.

- Evaluating research.

- Establishing international linkages.

To study the role of "faculty committees/ boards" systematically, we constructed the composite "Index of Collegiality" by aggregating and averaging answers indicating "faculty committees/ boards" as the actor having the primary influence in decisionmaking by full-time faculty employed in universities for all European countries. Collegial academic bodies in Poland are the most influential in Europe in deciding on new academic programs and teaching evaluation; and they are very influential in deciding on choosing new faculty, faculty promotion and tenure, budget priorities, teaching loads and research evaluation. They are less influential than the European average for deciding in only three areas: the selection of key administrators, admission standards, and internal research priorities (see Table A3 in the Data Appendix). Collegiality as the relative power of collegial bodies as seen through this index is very high in Poland (it is second only to Switzerland). Again, the Polish system is perceived by academics as a highly collegial one, in the sense that an uncommonly powerful role in taking academic decisions is played by academic collegial bodies.

In the perceptions of academics, the major features of Ian McNay's model of "collegium" are very strong: the value of "freedom" is stronger than the value of "equity", "loyalty" and "competence" (Clark, 1983); "collegiality" more important than the other three models "bureaucracy", "corporation" or "enterprise"; the role of the government is "permissive" rather than "regulatory", "directive" or "supportive", as in the other three models; the management style is "consensual" rather than "formal/ rational", "political/ tactical" or "developed leadership", as in the other three models. And finally, the administration serves the "academic community" rather than the "committee", "the chief executive" or the external or internal "client", as in the other three models. (From the perspective of Western European reports on Polish higher education, the system is too "democratic" in the sense of academic collegial bodies being responsible for too many aspects of university functioning).

When asked directly about a "top-down management style" (E4/3) and "collegiality in decision-making processes" (E4/4) in their institutions, Polish academics provide surprisingly average European responses. While they perceive Polish academic collegial bodies as very powerful, the share of responses agreeing or strongly agreeing to both the above issues is almost exactly the average for the eleven countries: with about a half ( 51 percent) for the former, and about a quarter (27 percent) for the latter. Thus, surprisingly, the perception of the influence of academic collegial bodies does not correspond to more general perceptions of their influence on academic decisions as seen through direct questions about top-down management styles and collegiality. Different

\footnotetext{
7 We omited the category of "students" in this study.
} 
Table 3

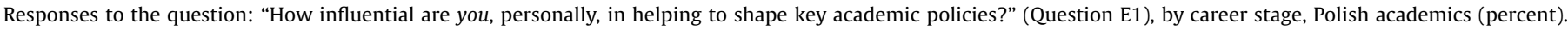

\begin{tabular}{|c|c|c|c|c|c|c|c|c|}
\hline & \multicolumn{2}{|c|}{ Very influential } & \multicolumn{2}{|c|}{ Somewhat influential } & \multicolumn{2}{|c|}{ A little influential } & \multicolumn{2}{|c|}{ Not at all influential } \\
\hline & $\begin{array}{l}\text { Full } \\
\text { professors }\end{array}$ & $\begin{array}{l}\text { New } \\
\text { entrants }\end{array}$ & $\begin{array}{l}\text { Full } \\
\text { professors }\end{array}$ & $\begin{array}{l}\text { New } \\
\text { entrants }\end{array}$ & Full professors & $\begin{array}{l}\text { New } \\
\text { entrants }\end{array}$ & Full professors & $\begin{array}{l}\text { New } \\
\text { entrants }\end{array}$ \\
\hline Department or similar unit & 32.1 & 8.7 & 44.9 & 27 & 18.8 & 44.9 & 4.2 & 19.4 \\
\hline Faculty or similar unit & 6.5 & 1.5 & 35.6 & 8.6 & 48.1 & 36.8 & 9.9 & 53.1 \\
\hline Institutional level & 3.6 & 0.8 & 9.8 & 2.7 & 44.0 & 17.8 & 42.7 & 78.7 \\
\hline
\end{tabular}

levels of collegiality seem to be taken as natural in different national systems - the high influence of faculty committees/ boards in Poland, surprisingly, is not viewed as a high level of academic collegiality in general or a low level of top-down management style in general. The share of academics agreeing with the statement on collegiality in their institutions (only 27 percent) is relatively low in the context of the analysis of the most influential actors in management and decision-making, indicating the pivotal role of academic collegial bodies (see Table A4 in Appendices).

\subsection{The junior-senior split in the Polish academic profession}

Finally, we explore briefly one more aspect of university governance: the distribution of influence and authority across academic career stages in a highly collegial system. The research puzzle we follow in this section is whether Polish collegiality is "the collegiality of the seniors", as the research literature strongly suggests. The junior-senior axis has often been a focus of higher education research (e.g. Finkelstein et al., 1998; Enders, 2000). For instance, the "deep rift" between the full professoriate and "the assistant class" in Continental academia was analyzed by Neave and Rhoades (1987, pp. 211-212). ${ }^{8}$

The stratification in the Polish "professorially-coordinated system" (as defined by Teichler et al., 2013, p. 191) is most fully expressed by the difference in academic power between "full professors" (those holding the Presidential professorial title, the pinnacle of the academic career) and "new entrants" to the academic profession (for our analyses, those granted their PhD degrees in the last ten years preceding the execution of the Polish part of the survey, that is in 2001-2010; in most cases meaning they would be in the 27-37 age bracket).

There are two interesting findings: first, the sharpness of the split between the two academic groups despite high levels of collegiality, and especially the important role of elected academic bodies, as perceived in Polish academia. And second, the positive perceptions by new entrants of current (still unreformed at the time of the survey execution in 2010) university management and organization in Poland compared with full professors. Based on an extensive review of the research literature on the stratification of the academic profession and the stratification of science (Cole and Cole, 1973; Zuckerman,1979; Finkelstein et al., 1998; Schuster and Finkelstein, 2006; Enders, 2000; Enders and de Weert, 2009), our initial hypothesis was that full professors in Poland would be much more appreciative of current university organization than new entrants. This hypothesis proved false in the Polish case. Appreciation of the unreformed system comes from new entrants

\footnotetext{
${ }^{8}$ For more detail regarding this dimension see also Clark's Academic Power in Italy. Bureaucracy and Oligarchy in a National University System, where academic padrone is studied under the headings of "local pyramids" and the "triumph of particularism",Clark, 1977, pp. 73-113; and, in an American context, by Martin J. Finkelstein, Robert K. Seal and Jack H. Schuster in their The New Academic Generation. A Profession in Transformation (1998: 101-112)
}

to a much higher degree. Surprisingly, the pervasiveness of the lack of personal influence among new entrants (compared with full professors) on shaping various academic policies does not seem to lead to negative perceptions of current university organization. The young generation, surprisingly, seems to be substantially more appreciative of the status quo in university organization and, consequently, they should be viewed as potential supporters of reforms to a much smaller degree than commonly assumed in Polish higher education reform literature and in national strategic documents and analyses (e.g. EY, 2010). This is a significant conclusion for the political economy of reforms which assumes reforms should be based on those internal stakeholders whose benefits are the highest and losses the lowest, and who therefore strongly support reforms and reformers. The professoriate is more critical of the organizational status quo than the new entrants to academia.

Polish new entrants show much lower personal influence than full professors at all three university levels studied. The distribution of their answers to the question "How influential are you, personally, in helping to shape key academic policies?" shows (Table 3 below) that at the department level one fifth report being "not at all influential", more than half at the faculty level, and almost four-fifths at the institutional level. The powerlessness of full professors is much less pronounced (under 5 percent at the first, under 10 percent at the second, and about 40 percent at the third level studied).

The Polish academy is a generationally divided institution: the split between professoriate and new entrants is powerful. Consequently, from a generational perspective, the collegiality prevalent in Poland can be viewed as "the collegiality of the seniors", to which juniors have only limited access. Surprisingly, and contrary to established views on the junior/senior split in higher education institutions, new entrants, despite their powerlessness in a professorially-dominated system, are much more highly appreciative of the current (that is, unreformed) university organization than the professoriate. The pervasiveness of the lack of personal influence among young academics on shaping various academic policies does not seem to lead to negative perceptions of the current university organization. Newcomers to academia show a much more positive attitude towards almost every aspects of the university mission: teaching, research, management, and services. They may have different expectations from their universities and may follow different norms, but they may also be more realistic about what is possible in their institutions, compared with other possibilities in other sectors of the economy.

\section{Conclusions}

This paper explored the extent to which selected university governance models developed in specific national contexts (Western Europe and the USA) are applicable to other national contexts (in this case, post-communist Poland). In particular, we were testing the applicability of the collegial model. Through a study of various academic attitudes and beliefs linked to different 
Table A1

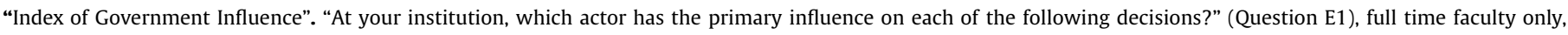
universities only, answer: "Government or external stakeholders" (in percent).

\begin{tabular}{|c|c|c|c|c|c|c|c|c|c|c|c|c|}
\hline & Austria & Finland & Germany & Ireland & Italy & Netherlands & Norway & Poland & Portugal & Switzerland & UK & Mean \\
\hline Selecting key administrators & 23.1 & 2.4 & 8.7 & 2.2 & 6.0 & 24.5 & 1.1 & 0.6 & 2.2 & 11.1 & 0.9 & 7.5 \\
\hline Choosing new faculty & 4.3 & 0.3 & 4.5 & 0.7 & 2.9 & 0.0 & 1.6 & 0.0 & 0.0 & 11.6 & 0.3 & 2.4 \\
\hline Making faculty promotion and tenure decisions & 0.8 & 0.2 & 2.2 & 0.7 & 4.2 & 0.0 & 2.5 & 1.7 & 0.7 & 1.5 & 0.0 & 1.3 \\
\hline Determining budget priorities & 8.4 & 4.1 & 5.3 & 3.8 & 1.8 & 0.7 & 1.9 & 5.2 & 8.1 & 10.5 & 3.9 & 4.9 \\
\hline Determining the overall teaching load of faculty & 0.9 & 3.6 & 100.0 & 0.2 & 2.3 & 0.0 & 3.8 & 0.1 & 0.8 & 5.3 & 0.5 & 10.7 \\
\hline $\begin{array}{l}\text { Setting admission standards for undergraduate } \\
\text { students }\end{array}$ & 15.8 & 9.7 & 10.7 & 16.6 & 6.4 & 5.7 & 12.8 & 0.7 & 12.0 & 13.4 & 2.7 & 9.7 \\
\hline Approving new academic programs & 6.5 & 14.8 & 8.7 & 0.9 & 2.2 & 5.0 & 0.0 & 2.1 & 6.4 & 6.7 & 2.1 & 5.0 \\
\hline Evaluating teaching & 0.7 & 5.1 & 2.1 & 1.1 & 0.9 & 4.0 & 1.9 & 0.5 & 3.5 & 3.0 & 5.6 & 2.6 \\
\hline Setting internal research priorities & 2.1 & 0.5 & 2.6 & 1.8 & 3.1 & 0.3 & 1.3 & 0.4 & 1.1 & 0.1 & 0.6 & 1.3 \\
\hline Evaluating research & 5.8 & 13.8 & 7.6 & 9.9 & 15.0 & 16.3 & 19.3 & 2.6 & 30.8 & 3.9 & 19.6 & 13.1 \\
\hline Establishing international linkages & 0.7 & 0.0 & 0.2 & 0.4 & 0.9 & 1.4 & 0.2 & 0.9 & 1.1 & 1.8 & 0.0 & 0.7 \\
\hline Total (Index) & 69.2 & 54.5 & 152.7 & 38.3 & 45.9 & 57.9 & 46.5 & 14.8 & 66.6 & 69.0 & 36.2 & 59.2 \\
\hline
\end{tabular}

Table A2

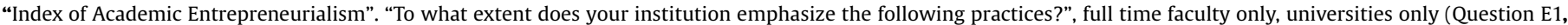
"from 1-very much, to 5-not at all; responses 1 and 2, "very much" and "a lot", are combined) (percentages) (percent agreeing).

\begin{tabular}{|c|c|c|c|c|c|c|c|c|c|c|c|}
\hline & Austria & Finland & Germany & Ireland & Italy & Netherlands & Norway & Poland & Portugal & UK & Mean \\
\hline Performance based allocation of resources to academic units & 43.9 & 61.3 & 55.3 & 28.0 & 29.4 & 63.9 & 54.1 & 36.6 & 18.6 & 39.6 & 43.1 \\
\hline $\begin{array}{l}\text { Considering the practical relevance/applicability of the work of } \\
\text { colleagues when making personnel decisions }\end{array}$ & 21.6 & 27.1 & 20.7 & 13.9 & 10.1 & 19.4 & 18.1 & 14.4 & 9.2 & 25.9 & 18.0 \\
\hline $\begin{array}{l}\text { Recruiting faculty who have work experience outside of } \\
\text { academia }\end{array}$ & 19.5 & 15.4 & 29.1 & 13.5 & 7.0 & 17.7 & 12.7 & 9.8 & 25.7 & 14.2 & 16.5 \\
\hline $\begin{array}{l}\text { Encouraging academics to adopt service activities/ } \\
\text { entrepreneurial activities outside the institution }\end{array}$ & 9.0 & 17.1 & 53.2 & 25.6 & 14.6 & 17.3 & 14.0 & 9.4 & 29.0 & 29.2 & 21.8 \\
\hline $\begin{array}{l}\text { Encouraging individuals, businesses, foundations etc. to } \\
\text { contribute more to higher education }\end{array}$ & 34.7 & 21.8 & 49.7 & 45.7 & 22.3 & 23.7 & 20.4 & 19.5 & 34.6 & 34.2 & 30.7 \\
\hline Total (Index) & 128.7 & 142.7 & 208.0 & 126.7 & 83.4 & 142.0 & 119.3 & 89.7 & 117.0 & 143.1 & 130.1 \\
\hline
\end{tabular}

models of university organization, we have been able to position the Polish higher education system among other European systems.

Our research results can be simplified in the following statement: Polish universities, studied here through Johan P. Olsen's theoretical models of university organization along with Robert Birnbaum's and Ian McNay's notions of academic collegiality, are operating according to the traditional collegial model of the university as a "community of scholars" to an extent unparalleled in Western Europe.

Our study demonstrates that the defining feature of Polish universities is powerful, unfading collegiality understood as strong academic collegial bodies. The influence of collegial bodies on academic decision-making is one of the highest in Europe, and the influence of the government and external stakeholders, in contrast - is the lowest in Europe. At the same time, the level of academic entrepreneurialism in Polish universities, usually linked to managerial rather than collegial management styles, is the lowest in Europe. Consequently, Polish higher education is one of the last remnants of the collegially-coordinated "republic of scholars" in Europe, albeit exposed to ever increasing national and international reform pressures.

Reform pressures lead to a conflict between the institutional vision of the university shared by the academic community (a value-based "community of scholars") and the instrumental vision shared by the policy-making community (an externally-driven, national, goal-oriented "organization"). The conflict is of fundamental policy importance because it is between "fundamental values" (Bowen and Schuster, 1986, p. 53) which cannot be easily reconciled. While in the Western European systems studied in this paper, the conflict between the Olsenian institutional vision and one of its instrumental visions (the university as an instrument for

Table A3

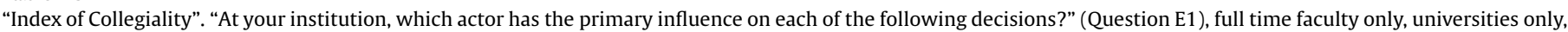
answer: "Faculty committees/boards" (in percent).

\begin{tabular}{|c|c|c|c|c|c|c|c|c|c|c|c|c|}
\hline & Austria & Finland & Germany & Ireland & Italy & Netherlands & Norway & Poland & Portugal & Switzerland & UK & Mean \\
\hline Selecting key administrators & 8.9 & 22.0 & 20.3 & 18.5 & 7.4 & 1.5 & 15.5 & 8.5 & 18.1 & 41.5 & 28.7 & 17.3 \\
\hline Choosing new faculty & 32.0 & 32.7 & 38.5 & 44.8 & 34.9 & 55.2 & 32.9 & 47.2 & 55.6 & 59.8 & 41.9 & 43.2 \\
\hline Making faculty promotion and tenure decisions & 4.3 & 47.0 & 12.9 & 58.0 & 33.6 & 37.0 & 32.5 & 60.4 & 50.1 & 73.7 & 52.2 & 42.0 \\
\hline Determining budget priorities & 2.6 & 23.7 & 11.2 & 19.5 & 20.7 & 15.2 & 20.4 & 22.5 & 8.5 & 44.4 & 27.1 & 19.6 \\
\hline Determining the overall teaching load of faculty & 9.6 & 24.2 & 0.0 & 14.0 & 45.1 & 41.1 & 21.4 & 68.5 & 52.3 & 67.4 & 29.2 & 33.9 \\
\hline $\begin{array}{l}\text { Setting admission standards for undergraduate } \\
\text { students }\end{array}$ & 18.0 & 42.5 & 27.1 & 38.7 & 53.9 & 38.6 & 41.2 & 33.8 & 41.2 & 58.1 & 44.0 & 39.7 \\
\hline Approving new academic programs & 21.0 & 41.3 & 25.0 & 68.2 & 68.9 & 28.4 & 0.0 & 73.7 & 54.3 & 60.4 & 57.0 & 45.3 \\
\hline Evaluating teaching & 11.1 & 22.4 & 25.2 & 23.0 & 34.7 & 31.5 & 20.1 & 44.0 & 23.6 & 36.0 & 32.3 & 27.6 \\
\hline Setting internal research priorities & 2.7 & 14.9 & 12.7 & 22.1 & 12.2 & 29.7 & 15.2 & 15.2 & 32.2 & 36.9 & 15.2 & 19.0 \\
\hline Evaluating research & 11.7 & 18.7 & 20.7 & 26.9 & 32.4 & 31.0 & 18.1 & 27.3 & 27.9 & 37.5 & 22.3 & 25.0 \\
\hline Establishing international linkages & 1.5 & 7.3 & 5.9 & 10.2 & 5.9 & 20.8 & 4.5 & 16.7 & 15.3 & 11.6 & 9.3 & 9.9 \\
\hline Total (Index) & 123.3 & 296.6 & 199.6 & 344.1 & 349.7 & 329.9 & 221.7 & 417.7 & 379.2 & 527.1 & 359.3 & 322.6 \\
\hline
\end{tabular}


Table A4

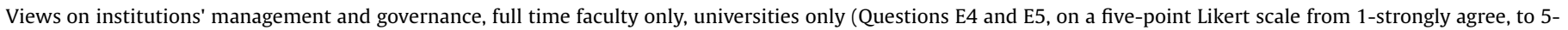
strongly disagree; responses 1 and 2, percent agreeing or agreeing strongly, are combined).

\begin{tabular}{|c|c|c|c|c|c|c|c|c|c|c|c|c|}
\hline & Austria & Finland & Germany & Ireland & Italy & Netherlands & Norway & Poland & Portugal & Switzerland & UK & Mean \\
\hline A strong emphasis on the institution's mission & 37.9 & 55.4 & 37.7 & 52.3 & 19.8 & 52.2 & 41.3 & 19.6 & 46.4 & 45.5 & 56.5 & 42.2 \\
\hline $\begin{array}{l}\text { Good communication between management and } \\
\text { academics }\end{array}$ & 18.8 & 32.0 & 19.0 & 18.9 & 26.0 & 26.4 & 34.6 & 21.7 & 28.9 & 35.4 & 20.6 & 25.7 \\
\hline A top-down management style & 62.9 & 52.5 & 44.9 & 75.9 & 52.0 & 53.1 & 29.6 & 51.4 & 45.4 & 42.4 & 59.2 & 51.7 \\
\hline Collegiality in decision-making processes & 22.4 & 26.2 & 27.8 & 17.3 & 15.8 & 32.6 & 24.5 & 26.9 & 36.3 & 43.9 & 19.7 & 26.7 \\
\hline A strong performance orientation & 49.9 & 59.3 & 0.0 & 54.3 & 21.7 & 71.2 & 51.8 & 57.7 & 37.8 & 45.3 & 71.9 & 47.4 \\
\hline A cumbersome admin. process & 75.3 & 57.3 & 71.0 & 80.1 & 53.2 & 53.8 & 55.6 & 70.0 & 55.3 & 52.4 & 70.7 & 63.2 \\
\hline $\begin{array}{l}\text { A supportive attitude of administrative staff } \\
\text { towards teaching activities }\end{array}$ & 26.1 & 25.7 & 27.6 & 29.9 & 18.9 & 48.4 & 43.6 & 29.8 & 31.5 & 41.4 & 39.7 & 33.0 \\
\hline $\begin{array}{l}\text { A supportive attitude of admin. staff towards } \\
\text { research activities }\end{array}$ & 33.7 & 25.1 & 24.7 & 51.0 & 17.1 & 35.8 & 36.0 & 24.1 & 15.7 & 50.3 & 38.6 & 32.0 \\
\hline $\begin{array}{l}\text { Professional development for administrative/ } \\
\text { management duties for individual faculty }\end{array}$ & 39.1 & 24.8 & 20.3 & 46.2 & 4.6 & 26.0 & 10.2 & 16.3 & 9.6 & 45.6 & 35.4 & 25.3 \\
\hline $\begin{array}{l}\text { Top-level administrators are providing competent } \\
\text { leadership }\end{array}$ & 39.1 & 40.9 & 34.0 & 27.4 & 32.2 & 41.8 & 37.8 & 24.8 & 42.5 & 39.3 & 22.0 & 34.7 \\
\hline $\begin{array}{l}\text { I am kept informed about what is going on at this } \\
\text { institution }\end{array}$ & 56.9 & 44.4 & 50.9 & 33.7 & 41.3 & 44.0 & 38.0 & 34.8 & 35.6 & 40.7 & 32.0 & 41.1 \\
\hline Lack of faculty involvement is a real problem & 63.3 & 28.7 & 44.3 & 59.6 & 39.2 & 28.2 & 34.8 & 18.4 & 55.1 & 32.6 & 38.4 & 40.2 \\
\hline $\begin{array}{l}\text { Students should have a stronger voice in } \\
\text { determining policy that affects them }\end{array}$ & 42.6 & 28.4 & 40.1 & 33.8 & 30.9 & 13.9 & 27.7 & 29.6 & 26.6 & 23.8 & 28.8 & 29.7 \\
\hline The administration supports academic freedom & 41.5 & 23.7 & 38.6 & 38.7 & 47.2 & 49.6 & 30.8 & 17.9 & 40.8 & 50.6 & 46.9 & 38.8 \\
\hline
\end{tabular}

national political agendas) has been present for several decades now, in Poland the conflict is only beginning to emerge.

The most collegial ("professorially-coordinated" and governed by institutional logic known as the "the republic of scholars" model) system in Europe is still awaiting the implementation of reforms to bring it closer to other European systems, already governed by instrumental logic and already involved in powerful, large-scale government-led reforms. But one of the lessons for Poland from reforms in Western European systems is that reforms unavoidably tend to lead to "further reforms" because policymakers in the last few decades tend to view universities as still "incomplete" organizations (Brunsson, 2009; Kwiek, 2013a). Consequently, Polish universities, still not "complete" organizations, can be expected to be a "work in progress" in the coming years to a much higher degree than the academic profession wishes or imagines, leading to a new wave of value-driven conflicts.

\section{Acknowledgements}

The author gratefully acknowledges the support of the National Research Council (NCN, grant DEC-2011/02/A/HS6/00183). The author wishes to thank Ulrich Teichler, the coordinator of the European Science Foundation EUROAC project, "Academic Profession in Europe: Responses to Societal Challenges", and Dr. Wojciech Roszka for his assistance.

\section{Appendix A.}

See Tables A1-A4.

\section{References}

Amaral, Alberto, Guy Neave, Christine Musselin, Peter Maassen, (Eds.), 2009. European Integration and the Governance of Higher Education and Research. Springer, Dordrecht.

Birnbaum, R., 1988. How Colleges Work: The Cybernetics of Academic Organization and Leadership. Jossey-Bass Publishers., San Francisco.

Bleiklie, I., Kogan, M., 2007. Organization and Governance of Universities. Higher Educ. Quart. 20, 477-493.

Bowen, H.R., Schuster, J.H., 1986. American Professors. A National Resource Imperiled. Oxford University Press, New York and Oxford.

Brunsson, N., 2009. Reform as Routine: Organizational Change and Stability in the Modern World. Oxford University Press, New York.
Clark, B.R., 1977. Academic Power in Italy. Bureaucracy and Oligarchy in a National University System. The Unieversity of Chicago Press, Chicago.

Clark, B.R., 1983. The Higher Education System. Academic Organization in CrossNational Perspective. University of California Press, Berkeley.

Cole, J.R., Cole, S., 1973. Social Stratification in Science. The University of Chicago Press, Chicago.

Creswell, J.W., 2009. Research Design: Qualitative, Quantitative, and Mixed Methods Approaches. SAGE Publications, Thousand Oaks.

De Boer, H., Enders, J., Schimank, U., 2007. on the way towards new public management? The governance of university systems in England, the Netherlands, Austria and Germany. In: Dorothea Jansen (Ed.), New Forms of Governance in Research Organizations. Disciplinary Approaches, Interfaces and Integration. Springer, Dordrecht, pp. 137-152.

Dobbins, M., 2015. Exploring the Governance of Polish Higher Education: Balancing Restored Historical Legacies with Europeanization and Market Pressures. Eur. J. High. Educ. 1, 18-33.

Dobbins, M., Knill, C., 2009. Higher Education Policies in Central and Eastern Europe: Convergence Toward a Common Model? Governance 22 (3), 397-430.

EY, 2010. The strategy for the development of higher education in Poland until 2020 Ernst and Young and IBNGR (in Polish), Warsaw.

Enders, J. (Ed.), 2000. Employment and Working Conditions of Academic Staff in Europe. GEW, Frankfurt.

Enders, J., de Weert, E. (Eds.), 2009. The Changing Face of Academic Life: Analytical and Comparative Perspectives. Palgrave Macmillan, New York.

Finkelstein, M.J., 1984. The American Academic Profession. A Synthesis of Social Scientific Inquiry since World War II. Ohio State University Press, Columbus.

Finkelstein, M.J., Robert Seal, K., Schuster, J.H., 1998. The New Academic Generation. A Profession in Transformation. The Johns Hopkins University Press, Baltimore.

Fumasoli, T., Goastellec, G., Kehm, B.M. (Eds.), 2014. Academic Careers in Europe Trends, Challenges, Perspectives. Springer, Dordrecht.

Goodman, P., 1962. The Community of Scholars. Random House, New York.

Goodwin, J., 2012. Secondary sources and secondary analysis. In: Goodwin, J. (Ed.), SAGE Secondary Data Analysisi, Vol. 1. SAGE, London, pp. xix-xxxviii.

Hibberts, M., Burke Johnson, R., Hudson, K., 2012. Common Survey Sampling Techniques. In: Lior Gideon (Ed.), Handbook of Survey Methodology for the Social Sciences. Springer, Dordrecht, pp. 53-74.

Huang, F., Finkelstein, M., Rostan, M., 2014. The Internationalization of the Academy. Changes, Realities and Prospects. Springer, Dordrecht.

Huisman, J., 2009. Coming to Terms with Governance in Higher Education. In: Huisman, J. (Ed.), International Perspectives on the Governance of Higher Education: Alternative Frameworks for Coordination. Routledge, New York, pp. $1-9$.

Huisman, Jeroen, Peter Maassen, Guy Neave, (Eds.), 2008. Higher Education and the Nation State: The International Dimension of Higher Education. Emerald Group Publishing, Bingley.

Białecki, I., Dąbrowa-Szefler, M., 2009. Polish higher education in transition: between policy making and autonomy. In: Palfreyman, D. (Ed.), Structuring Mass Higher Education: The Role of Elite Institutions. Routledge, London.

Kwiek, M., 2003. Academe in transition: Transformations in the polish academic profession. Higher Educ. 45 (4), 455-476.

Kwiek, M., 2009a. The two decades of privatization in polish higher education. CostSharing, Equity and Access. In: Knight, J. (Ed.), Financing Access and Equity in Higher Education. Sense, Rotterdam/Boston/Taipei, pp. 149-168. 
Kwiek, M., 2009b. The changing attractiveness of european higher education: current developments, future challenges, and major policy issues. In: Kehm, B., Huisman, J., Stensaker, B. (Eds.), The European Higher Education Area: Perspectives on a Moving Target. Sense, Rotterdam, pp. 107-124.

Kwiek, M., 2012. Changing higher education policies: from the deinstitutionalization to the reinstitutionalization of the research mission in polish universities. Sci. Pub. Pol. 39, 641-654.

Kwiek, M., 2013a. Knowledge Production in European Universities. States, Markets, and Academic Entrepreneurialism. Peter Lang, Frankfurt and New York.

Kwiek, M., 2013b. From system expansion to system contraction: access to higher education in poland. Comp. Educ. Rev. 57 (3(Fall)), 553-576.

Kwiek, M., 2014a. The internationalization of the polish academic profession. A european comparative approach. Zeitschrift für Pädagogik 60 (5), 681-695.

Kwiek, M., 2014b. Structural changes in the polish higher education system (19902010): a synthetic view. Eur. J. Higher Educ. 4 (3), 266-280.

Kwiek, M., 2015a. The internationalization of research in europe. A quantitative study of 11 national systems from a micro-level perspective. J. Stud. Intern. Educ. doi:http://dx.doi.org/10.1177/1028315315572898 Online First: February 25, 2015.

Kwiek, M., 2015b. Inequality in academic knowledge production. The role of research top performers across europe. In: Reale, E., Primeri, E. (Eds.), Universities in transition. Shifting institutional and organizational boundaries. Sense, Rotterdam in press.

Kwiek, M., Antonowicz, D., 2015. The changing paths in academic careers in european universities: minor steps and major milestones. In: Fumasoli, T., Goastellec, G., Kehm, B.M. (Eds.), Academic Work and Careers in Europe: Trends, Challenges, Perspectives. Springer, Dordrecht.

Locke, W., 2011. The international study of the changing academic profession: a unique source for examining the academy's perceptions of governance and management in comparative perspective. In: Locke, W., Cummings, W.K., Fischer, D. (Eds.), Changing Governance and management in Higher Education. Springer, Dordrecht, pp. 381-384.

Locke, W., William, K.C., Fischer, D. (Eds.), 2011. Changing Governance and management in Higher Education. Springer, Dordrecht.

University Dynamics and European Integration. In: Maassen, P., Olsen, J.P. (Eds.), Springer, Dordrecht.

Magalhaes, A., Amaral, A., 2009. Mapping Out Discourses on Higher Education Governance. In: Jeroen, H. (Ed.), International Perspectives on the Governance of Higher Education: Alternative Frameworks for Coordination. Routledge, New York, pp. 182-197.

Manning, K., 2013. Organizational Theory in Higher Education. Routledge, London.

Mesch, G., 2012. E-mail surveys. In: Lior Gideon (Ed.), Handbook of Survey Methodology for the Social Sciences. Springer, Dordrecht, pp. 313-326.
Millett, J.D., 1962. The Academic Community. An Essay on Organization. McGrawHill, New York.

Morgan, G., 1986. Images of Organization. Sage, Beverly Hills.

Neave, G., 2012. The Evaluative State, Institutional Autonomy and Re-Engineering Higher Education in Western Europe: The Prince and His Pleasure. Palgrave Macmillan, Basingstoke.

Neave, G., Rhoades, G., 1987. The Academic Estate in Western Europe. In: Clark, B.R. (Ed.), The Academic Profession. National, Disciplinary and Institutional Settings. University of California Press, Berkeley, pp. 211-270.

Neave, Guy, Frans A. van Vught, (Eds.), 1994. Government and Higher Education Relationships Across Three Continents: The Winds of Change. Pergamon, Oxford.

Neave, Guy, Frans van Vught, (Eds.), 1991. Prometheus Bound: The Changing Relationship between Government and Higher Education in Western Europe. Pergamon Press, Oxford and New York.

Johan Olsen, P., 2007. The Institutional Dynamics of the European University. In: Johan Olsen, P., Peter, M. (Eds.), University Dynamics and European Integration. Springer, Dordrecht, pp. 25-54.

Pinheiro, R., Antonowicz, D., 2014. Opening the Gates or Coping with the Flow? Governing Access to Higher Education in Northern and Central Europe. Higher Education doi:http://dx.doi.org/10.1007/s10734-014-9830-1 On-line first: 27 November 2014

Rhoades, G., 1992. Governance Models. In: Clark, B.R., Neave, G. (Eds.), The Encyclopedia of Higher Education Analytical Perspectives., vol. 2. Pergamon, Oxford, pp. 1376-1384.

Schuster, J.H., Finkelstein, M.J., 2006. The American Faculty. The Restructuring of Academic Work and Careers. Johns Hopkins University Press, Baltimore.

Shattock, M., 2006. Managing Good Governance in Higher Education. Open University Press, Maidenhead.

Shin, J.C., Akira, A., Cummings, W.K., 2014. Teachimg and Research in Contemporary Higher Education. Systems, Activities and Rewards. Springer, Dordrecht.

Stoop, I., 2012. Unit Non-Response Due to Refusal. In: Gideon, L. (Ed.), Handbook of Survey Methodology for the Social Sciences. Springer, Dordrecht, pp. 121-147.

Teichler, U., Akira, A., Cummings, W.K., 2013. The Changing Academic Profession. Major Findings of a Comparative Survey. Springer, Dordrecht.

Teichler, Ulrich, Ester Eva Höhle, (Eds.), 2013. The Work Situation of the Academic Profession in Europe: Findings of a Survey in Twelve Countries. Springer, Dordrecht.

Tight, M., 2012. Researching Higher Education. Second Edition. SRHE and Open University Press, Buckingham.

World Bank/EIB, 2004. Tertiary Education in Poland. World Bank/European Investment Bank, Warsaw.

Zuckerman, H., 1979. Scientific Elite: Nobel Laureates in the United States. New Brunswick. Transaction Publishers.. 